\title{
Area Under the First Moment Curve From Dosing to Last Concentration
}

National Cancer Institute

\section{Source}

National Cancer Institute. Area Under the First Moment Curve From Dosing to Last

Concentration. NCI Thesaurus. Code C85569.

The area under the moment curve (AUMC) from the time of dosing to the last

measurable concentration. 